Review

\title{
QUANTITATIVE ECONOMICS AS A SCIENTIFIC APPROACH TO THE SOLUTION OF PROBLEMS OF A COMPLEX NATURE - IN HONOR OF PROFESSOR WILLEM KAREL M. BRAUERS ON THE OCCASION OF HIS $90^{\text {th }}$ BIRTHDAY
}

\author{
Hatem MASRI \\ Department of Management and Marketing, College of Business Administration, \\ University of Bahrain, P.O. Box 32038, Bahrain
}

Received 16 August 2014; accepted 14 September 2014

\begin{abstract}
In the previous century Quantitative Economics substantially evolved in the direction of Mathematical Economics, Econometrics and Operational Research. Professor Willem Karel M. Brauers sees it mainly as a scientific approach to the solutions of problems of a complex nature by Methods such as Input-Output Analysis and Multi-Objective Optimization. At the occasion of his $90^{\text {th }}$ birthday this article highlights the research of Professor Willem Karel M. Brauers, presents a review of his extensive scientific work and lists some of his publications.
\end{abstract}

Keywords: Quantitative economics, Input-Output Analysis, Multi-Objective Optimization, MOORA, MULTIMOORA, Willem Karel M. Brauers.

JEL Classification: B3, C6.

\section{Introduction}

Input-Output Analysis is defined as the empirical application of general interdependence to a study of interrelations among the factors of production, the outputs and the components of final demand. Instead of considering economic good by economic good as Walras has done, W. W. Leontief, the father of the Input-Output Analysis, aggregated the economic goods to activity sectors, arriving at a table from 30 till different hundreds of production sectors depending of the size of the country and the availability of statistics. From the relations between the production sectors Technical Coefficients are derived, characterized with a certain behavior and with creating possibilities of forecasting. If from the production of the sectors a refined composition of final demand is derived, the inverse will tell for a given 
demand which production is needed. Production Multipliers per decomposition of final demand resulting in productions per sector are a next instrument for economic analysis. In this way Input-Output is a strong instrument for economic analysis, economic policy and economic forecasting (Brauers 1975).

A first Input-Output Table for Belgium was made by the University of Brussels for the year 1953 (Kirshen, de Falleur 1958). A second table was made by Brauers for 1958 (Brauers 1964a, 1965a, 1965b). For 1959 and later the work was taken over by the European Union.

After the example of Prof. Isard, a follower of Leontief, who constructed regional input-output tables for the US, Brauers published regional I-O tables for Belgium and even regional Balances of Payments, an effort which was not repeated up till now (Brauers 1980). Most of this previous work was published in Dutch (Brauers 1961, 1964b).

The doctoral thesis of Prof. Brauers, with a preface from W. W. Leontief, concerns the Input-Output Analysis applied on European Integration (Brauers 1968).

As previously I-O Analysis was not well known in France, Brauers wrote a book on this subject in French (Brauers 1995).

During these analyses it became clear for Brauers that a time horizon was important. For instance, profit maximization is only a notion in the short term. In the long run one has to think rather in terms of Cash Flows, Net Present Value and Internal Rate of Return. Brauers illustrated this point with a very extensive case study (Brauers 1990).

\section{Studies on National Defense}

Mostly on demand of the National Department of National Defense Brauers made many studies on the repercussions of National Defense on the national economy (Brauers 1960).

A NATO Fellowship (1971) presented the occasion to write a book on Systems Analysis with special reference to national defense (Brauers 1976).

Brauers wrote a critical book on the organization of Belgian military defense (Brauers 1993). In 2002 Brauers wrote an article in which he stipulated, when for Belgium the replacement of the fighter plane F16 by the Lockheed Joint Strike Fighter was suggested, that this last one already was outdated against planes of a new generation (Brauers 2002). Updated two times the F16 can remain operational until 2023, but at that time the Joint Strike Fighter will be outdated too, a new generation plane would be too expensive for Belgium, a European Defense Community may take shape and developments of another kind, like further development of unmanned armed drones, could change the picture.

\section{Achievements in development of MODM methods}

During a visit at Rand Corporation in 1971 Brauers got acquainted with the Additive Weighting Procedure of MacCrimmon, meaning his first contact with a Multiple Objective Decision Making Method (MacCrimmon 1968). From that moment on he dislikes weights in that context, as weights in Multi-Objective Optimization have an ambiguous meaning: normalization on the one side and importance on the other. Therefore Brauers made a search for alternative methods. 
In connection with his work for the Belgian Defense Department Brauers developed his first Multi-Objective Decision Making Method: the Indifference Method (Brauers 1977). The main decision maker, here the Defense Department, is indifferent in the choice between different solutions towards multiple objectives. At that moment the economic costs will decide. For instance, the Belgian Army had to decide to purchase 6 tons heavy trucks. The candidate trucks had to undergo heavy tests: to climb slopes of 70\%, to drive through 1.60 meter of water, to stay in the water for some time, to take a lot of obstacles, to use consecutively petrol and light fuel etc. Finally the military specialists were indifferent between limited number types of trucks. At that moment the economists entered into the picture: the lowest budgetary cost decided upon the choice, which was finally the MAN heavy truck.

Brauers had a reflection period for some time, considering the link of Multi-Objective reasoning with economics, econometrics and general economic interdependence, finally resulting in a 2004 book presented as a "Revolution in Economic Thinking by Multi-Objective Optimization" (Brauers 2004a).

MOORA was first used in an article of 2004 (Brauers 2004b), but the name was only given in 2006 (Brauers, Zavadskas 2006). MOORA stands for Multi-Objective Optimization on basis of Ratio Analysis, which goes for a Decision Matrix of alternative solutions responding to different objectives, on which ratios are applied. The responses of the different alternative solutions per objective (or criterion, a weaker form of an objective) forms a column of the matrix. With weighting methods this matrix is read horizontally and as Brauers is allergic for weights, he reads the matrix vertically. For each column a ratio as a dimensionless measurement is calculated. These ratios are not averages, as an eventual negative denominator would make the fraction senseless. Therefore the denominator is changed in such a way that it is always positive.

A second Method in MOORA is the Reference Point Approach which will use the ratios found earlier and whereby also a Maximal Objective Reference Point is used. The Maximal Objective Reference Point approach is called realistic and non-subjective as the co-ordinates $\left(r_{i}\right)$, which are selected for the reference point, are realized in one of the candidate alternatives. In the example, A $(10 ; 100), B(100 ; 20)$ and C $(50 ; 50)$, the maximal objective reference point $\mathrm{R}_{m}$ results in: $(100 ; 100)$. Per objective the coordinates of the corresponding ratio are subtracted from the coordinates of the Reference Point.

Then this matrix is subject to the Metric of Tchebycheff:

$$
\underset{(j)}{\operatorname{Min}}\left\{\max _{(i)}\left|r_{i}-x_{i j}^{*}\right|\right\},
$$

$r_{i}=$ the $i^{\text {th }}$ co-ordinate of the reference point;

$x_{i j}^{*}=$ the dimensionless measurement of objective $i$ for alternative $j$;

$i=1,2 \ldots n$; $n$ the number of objectives;

$j=1,2 \ldots m ; m$ the number of alternatives;

with $\left|r_{i}-x_{i j}^{*}\right|$ the absolute value, necessary if $x_{i j}^{*}$ is larger than $r_{i}$. 
Brauers applied MOORA in micro-economics such as for:

- Redevelopment of derelict and mismanagement buildings in Lithuanian rural areas (Brauers et al. 2006a);

- Location Theory with a simulation for a Department Store (Brauers, Zavadskas 2008);

- Contractor's Ranking for dwellings in Vilnius (Brauers et al. 2008b);

- A side step on consumer sovereignty (Brauers 2008b);

- The facilities Sector (Brauers, Zavadskas 2009a);

- Project Analysis (Brauers, Zavadskas 2009b).

Brauers applied MOORA in macro-economics such as for:

- Privatization (Brauers, Zavadskas 2006);

- Sustainable Development in Lithuania and Poland (Brauers et al. 2006b);

- The European Union in a Transition Economy (Brauers et al. 2007);

- Road Design Alternatives (Brauers et al. 2008a);

- Regional economics for Lithuania (Brauers, Ginevičius 2009);

- Seaport Planning (Brauers 2013).

MOORA can it be called Robust? Characteristics of Robustness in Multi-Objective Optimization (Brauers, Zavadskas 2009a, 2012 a; Brauers, Ginevičius 2009, 2010):

1. All stakeholders are involved (assistance can be given by the Ameliorated Nominal Group Technique, see underneath).

2. Respect for Consumer Sovereignty (Brauers 2008b).

3. All non-correlated objectives are involved, as much as possible (see e.g. Brauers et al. 2008b).

4. All interrelations between objectives and alternatives are considered at the same time and for instance not two by two (otherwise a victim of the Condorcet-Arrow Paradox, see e.g. Brauers 2004a: 118-124).

5. Non-subjective as much as possible:

- in the choice of the objectives (assistance can be given by the Ameliorated Nominal Group Technique, see underneath);

- to give importance to an objective (assistance can be given by the Delphi Method, see underneath);

- omitting Normalization. Dimensionless Measurements as used here are preferred to weights, which need normalization (for normalization, see: Brauers, Zavadskas 2007; Brauers 2007a, 2007b).

6. Based on Cardinal Numbers more robust than on Ordinal Numbers.

7. Uses the most recent available data.

8. The use of 2 different methods of MOO is more robust than using a single one. Nevertheless contradiction between the two methods remains possible. Therefore a third dimensionless measurements method is introduced: the Full Multiplicative Method. The thee methods are gathered under the name of MULTIMOORA. An Ordinal Dominance Theory will take care of the final ranking for the 3 methods. 


\section{MULTIMOORA}

\section{The full multiplicative form}

Per row of an alternative all objectives are simply multiplied, but the objectives to be minimized are a part of the multiplication process in a denominator. A single zero or a negative number for one of the objectives would make the final product zero or entirely negative. In order to escape of this nonsense solution, 100 replaces zero and for instance 2 becomes 102 and -2 becomes 98 but only for the objective under consideration.

\section{Ordinal dominance theory}

Dominance. Absolute Dominance means that an alternative, solution or project is dominating in ranking all other alternatives, solutions or projects which are all being dominated. This absolute dominance shows as rankings for MULTIMOORA: (1-1-1).

General Dominance in two of the three methods is of the form, with $\mathrm{a}<\mathrm{b}<\mathrm{c}<\mathrm{d}$ :

$(\mathrm{d}-\mathrm{a}-\mathrm{a})$ is generally dominating $(\mathrm{c}-\mathrm{b}-\mathrm{b})$;

$(a-d-a)$ is generally dominating $(b-c-b)$;

$(\mathrm{a}-\mathrm{a}-\mathrm{d})$ is generally dominating $(\mathrm{b}-\mathrm{b}-\mathrm{c})$;

and further transitiveness plays fully.

Transitiveness. If $a$ dominates $b$ and $b$ dominates $c$ than also $a$ will dominate $c$.

Overall Dominance of one alternative on the next one. For instance $(\mathrm{a}-\mathrm{a}-\mathrm{a})$ is overall dominating ( $b-b-b)$ which is overall being dominated.

Equability. Absolute Equability has the form: for instance (e-e-e) for 2 alternatives. Partial Equability of 2 on 3 exists e. g. (5-e-7) and (6-e-3).

- Brauers applied MULTIMOORA in micro-economics such as for:

- Heating Losses in a Building (Kračka et al. 2010);

- Bank loan to buy Property (Brauers, Zavadskas 2011);

- Buildings from the Soviet Period (Brauers et al. 2012a);

- Happiness is very subjective and difficult to specify. Therefore limited to side conditions like health, age, education, free of pollution and economic welfare. Which country fulfills the best the directives of the EU on these points (Brauers et al. 2012b)?

- To invest in which Belgian Shares (Brauers, Ginevičius 2013)?

- Which Lithuanian Bank did rate the best after the recession 2008-2009 (Brauers et al. 2014a, 2014b)?

Brauers applied MULTIMOORA in macro-economics such as for:

- Optimality for the Belgian Regions (Brauers, Ginevičius 2010);

- Project Management in Transition Economies (Brauers, Zavadskas 2010a);

- Which Input-Output sector will stimulate Tanzania's economy the most (Brauers, Zavadskas 2010b)?

- European Integration updated with Fuzzy Number Theory (Brauers et al. 2011);

- Project Selection for the Tunisian Textile Industry (Brauers, Zavadskas 2012b);

- Project Management for a Country with Multiple Objectives (Brauers 2012);

- Implementing the EU Strategy in Baltic States (Brauers et al. 2012c); 
- The Construction Sector during the recession (Brauers et al. 2013);

- A new Rating System for Countries opposed to the traditional Credit Rating Agencies (Brauers, Zavadskas 2013);

- Was the Construction Sector Anti-Cyclical during the recession 2008-2009 (Brauers et al. 2014c)?

\section{Ameliorated Nominal Group Technique and Delphi to support MULTIMOORA}

Ameliorated Nominal Group Technique: A group of especially knowledgeable individuals, representing all stakeholders, is formed and comes together in a closed meeting. This group of participants is asked to generate and write down ideas about the problem under examination without any contact with the other participants. Voting takes place on all ideas. The outcome is the totality of the individual votes. The group is also questioned about the probability of occurrence of the event. The probability of the group is found as the median of the individual probabilities. Finally, the group rating is multiplied with the group probability in order to obtain the effectiveness rate. The Ameliorated Nominal Group Technique is used for MULTIMOORA to generate Objectives (Brauers, Lepkova 2002, 2003).

Delphi Method: The Delphi Method is a method for obtaining and processing judgmental data. It consists of a sequenced program of separate interrogation (in session or by mail) interspersed with feedback of persons interested in the issue, while everything is conducted through a steering group. The Delphi Method is used for MULTIMOORA to give importance to the objectives (Brauers 2004a, 2008a).

\section{Biography and general data}

Willem Karel M. Brauers is born in 1924, Antwerp, Flanders, Belgium. Brauers is married and has two married daughters. Brauers is veteran 1940 of World War II and he refused to work for the German occupants in 1943-1944. In High School he founded a student's club without permission of the occupying German invaders. After the Liberation, Brauers had the opportunity to pass the examination for his first year of Bachelor before a special jury. The second year of College was made practically impossible due the German flying bombs, mainly directed again the not destroyed port of Antwerp. Nevertheless he also studied dramatic arts in evening classes. Finally, registered in Leuven University in the city of Louvain he started with a theater group for students. At this university he successively obtained the degrees of Master in Applied Economics, Master in Economics, Master in Political and Diplomatic Sciences and Bachelor in Philosophy. Due to Fellowships of the Belgian-American Educational Foundation he obtained a Master of Arts in Economics at the Graduate School of Arts and Sciences of Columbia University, New York and spent one semester in the Harvard Economic Research Project of Harvard University under the guidance of Professor W. W. Leontief. In 1968 Brauers obtained his Ph. D. in Economics in Louvain University.

In 2011 he became Professor Honoris Causa of Vilnius Gediminas Technical University, mostly for his work on Multi-Objective Optimization. 


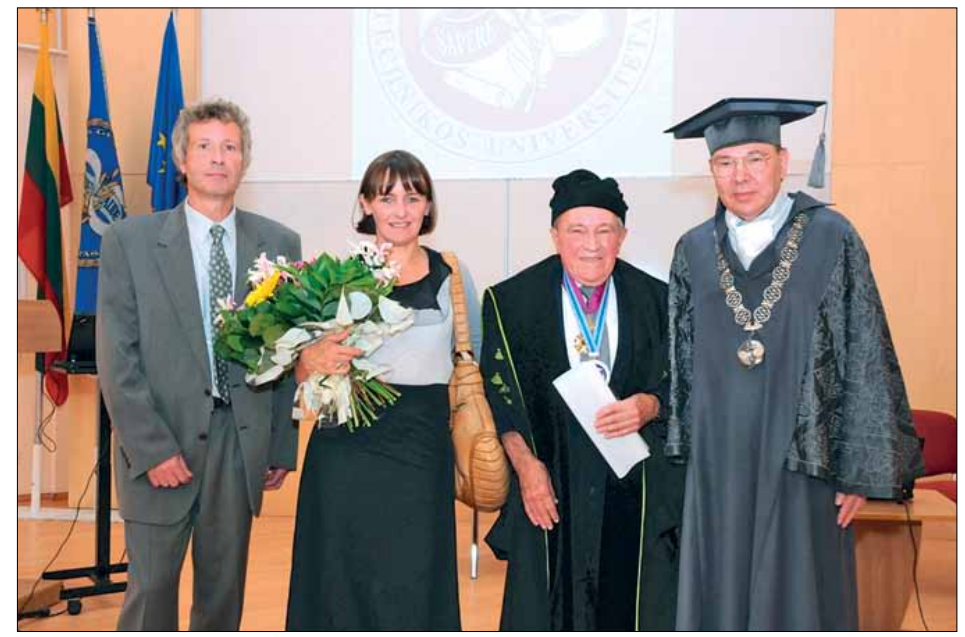

Fig. 2011: nomination as Honorary Doctor at Vilnius Gediminas Technical University of Prof. Brauers in presence of his daughter and son-in-law and with Prof. Zavadskas

Brauers got the following fellowships for Research:

- 1957 Council of Europe Fellowship, Strasbourg.

- 1970 Advanced Fellowship Belgian American Educational Foundation.

- 1971 NATO Fellowship for studying OR and Military Research.

- 1972 Laureate of a Belgian Government Travel Grant.

Functions outside Teaching:

- 1959-1978 Advisor to the Belgian Department of Defense.

- 1973-1981 Adviser to the Center for Economic Studies, University of Leuven.

- 1978-1984 Town Councilor City of Antwerp.

- 1978-2002 Member and afterwards Chairman of the Board of SORCA Ltd., Consulting Firm for Developing Countries, at that time member of the Worldwide Group of ARCADIS, Systems Engineers.

Field Work of Prof. Brauers:

- 1957 Member of the Belgian Economic Mission to China in order to recognize the People's Republic of China by Belgium.

- 1966 Reconversion for the province of Limburg due to the closing down of its coal mines.

- 1973 Study of Management Models for the main electricity works in Belgium.

- 1975 A location study for the new Port of Arzew (Algeria), at the moment the main world port for export of natural gas.

- 1976 An Anti-Pollution Model for the Economic Commission for Europe, UNO.

- 1983 Reconversion of the Walloon Steel Industry.

- 1988-1991 Organizing the industrial statistics for the Department of Industry, Government of Thailand. 
- 1991 For Central Bank of Madagascar and World Bank: Methodology for the economic evaluation of Projects for Developing Countries. The case of Madagascar.

Teaching:

- 1963-1990 Extra-Ordinal Professor Antwerp School of Business Administration.

- 1964-1969 Extra-Ordinal Professor School of Military Administrators, Postgraduate after the Royal Military University.

- 1969-1974 Associate Professor University of Leuven.

- 1971-1976 Extra-Ordinal Professor Belgian Military Staff College, preparation for Officers of Staff.

- 1984-1990 Head of the Chair for Development Planning and Forecasting, Postgraduate School for Developing Countries, University of Antwerp.

- 1974-up till now, Professor Ordinarius, Faculty of Applied Economics, University of Antwerp.

- 2001-2013 Visiting professor at Vilnius Gediminas Technical University.

\section{Conclusions}

Professor Willem Karel M. Brauers has greatly contributed to the development and practical applications of Multi-Objective Optimization Methods, aside from other contributions like concerning Input-Output Models. This is why a part of this article was devoted to his achievements.

Professor Willem Karel M. Brauers has greatly contributed to quantitative economics. His numerous publications on quantitative economics will encourage continuous innovations in this field.

On the day of his Jubilee, we would like to congratulate Professor Willem Karel M. Brauers, an exceptional scientist of greatest format. We wish the Professor good health and creativity in further contributions.

\section{References}

Brauers, W. K. M. 1960. Répercussions des dépenses de défense sur léconomie nationale. Center for Economic Studies, Department of National Defense, Brussels.

Brauers, W. K. M. 1961. Input-Output Bibliography 1955-1960. United Nations, New York. 4 p.

Brauers, W. K. M. 1964a. De opstelling van een input-output tabel voor de Belgische economie in 1958 [The setting up of an Input-Output table for the Belgian economy in 1958], Cahiers économiques de Bruxelles (21): 115-136.

Brauers, W. K. M. 1964b. International Bibliography on Income and Wealth. International Association for Research in Income and Wealth, New Haven, 55, 58, 155: 164-165.

Brauers, W. K. M. 1965a. De evolutie van de input-output technische coëfficiënten met bijzondere toepassing voor België [The evolution of the I-O technical coefficients especially applied for Belgium], Revue belge de Statistique et de Recherche Opérationnelle 6(1): 11-40.

Brauers, W. K. M. 1965b. De geïnverteerde matrix voor de Belgische economie in 1958 [The inverted matrix for the Belgian economy in 1958], Cahiers économiques de Bruxelles (25): 95-104. 
Brauers, W. K. M. 1968. Input-Output Analyse en Internationale Economische Integratie [Input-output analysis and international economic integration], with a Preface by Prof. W. Leontief, Standaard Wetenschappelijke Uitgeverij, Antwerpen-Utrecht.

Brauers, W. K. M. 1975. Leontief, the Nobel Prize winner and his input-output analysis. ACCO, Leuven, Belgium.

Brauers, W. K. M. 1976. Systems analysis, planning and decision models with special reference to national defense. Amsterdam, New York: Elsevier.

Brauers, W. K. M. 1977. Multiple criteria decision making and the input-output model for national defense. Civil Administration of the Belgian Department of National Defense, Brussels.

Brauers, W. K. M. 1980. The Belgian experience in interregional input-output tables. Center for Economic Studies, Catholic University of Leuven.

Brauers, W. K. M. 1990. Multiple criteria decision making in industrial project management, Engineering Costs and Production Economics (20): 231-240. http://dx.doi.org/10.1016/0167-188X(90)90106-R

Brauers, W. K. M. 1993. Ons leger waakt! Waakt ons leger wel? [Our military defense is awake. Is our military defense awake?]. Antwerpen: de Vries-Brouwers.

Brauers, W. K. M. 1995. Prévisions Economiques a l'aide de la méthode Entrées-Sorties. Paris: Economica.

Brauers, W. K. M. 2002. The multiplicative representation for multiple objectives optimization with an application for arms procurement, Naval Research Logistics 49: 327-340. Wiley Periodicals. http://dx.doi.org/10.1002/nav.10014

Brauers, W. K. M. 2004a. Optimization methods for a stakeholder society, a revolution in economic thinking by multi-objective optimization, Series: Nonconvex Optimization and its Applications, vol. 73. Boston-Dordrecht-London: Kluwer Academic Publishers, Springer. http://dx.doi.org/10.1007/978-1-4419-9178-2

Brauers, W. K. M. 2004b. Multi-objective optimization (MOO) in privatization, Journal of Business Economics and Management 5(2): 59-65.

Brauers, W. K. M. 2007a. What is meant by normalisation in decision making?, International Journal of Management and Decision Making 8(5-6): 445-460. http://dx.doi.org/10.1504/IJMDM.2007.013411

Brauers, W. K. M. 2007b. Normalisation in multiobjective optimisation: a general overview, International Journal of Management and Decision Making 8(5-6): 461-474. http://dx.doi.org/10.1504/IJMDM.2007.013412

Brauers, W. K. M. 2008a. Group decision making with multi-objective optimization, Foundations of Computing and Decision Sciences 33(2): 167-179. Poznan University, Poland.

Brauers, W. K. M. 2008b. Multi-objective decision making by reference point theory for a wellbeing economy, Operations Research International Journal 8(1): 89-104.

Brauers, W. K. M. 2012. Project management for a country with multiple objectives, Czech Economic Review 6(1): 80-101. The Faculty of Social Sciences, Charles University in Prague.

Brauers, W. K. M. 2013. Multi-objective seaport planning by MOORA decision making, Annals of Operations Research 206(1): 39-58. http://dx.doi.org/10.1007/s10479-013-1314-7

Brauers, W. K. M.; Ginevičius, R. 2009. Robustness in regional development studies. The case of Lithuania, Journal of Business Economics and Management 10(2): 121-140. http://dx.doi.org/10.3846/1611-1699.2009.10.121-140

Brauers, W. K. M.; Ginevičius, R. 2010. The economy of the Belgian regions tested with MULTIMOORA, Journal of Business Economics and Management 11(2): 173-209. North-German Academy of Informatology. http://dx.doi.org/10.3846/jbem.2010.09

Brauers, W. K. M.; Ginevicius, R. 2013. How to invest in Belgian shares by MULTIMOORA optimization, Journal of Business Economics and Management 14(5): 940-956.

http://dx.doi.org/10.3846/16111699.2013.837244 
Brauers, W. K. M.; Lepkova, N. 2002. The application of the nominal group technique to the economic outlook of Lithuania over the period 2002-2011, Technological and Economic Development of Economy 8(1): 19-24.

Brauers, W. K. M.; Lepkova, N. 2003. The application of the nominal group technique to the business outlook of the facilities sector of Lithuania over the period 2003-2012, International Journal of Strategic Property Management 7(1): 1-9.

Brauers, W. K. M.; Zavadskas, E. K. 2006. The MOORA method and its application to privatization in a transition economy, Control and Cybernetics 35(2): 445-469.

Brauers, W. K. M.; Zavadskas, E. K. 2007. Editorial. Normalisation in decision making methods, International Journal of Management and Decision Making 8(5-6): 441-444.

Brauers, W. K. M.; Zavadskas, E. K. 2008. Multi-objective optimization in location theory, with a simulation for a department store, Transformations in Business \& Economics 7(3): 163-183.

Brauers, W. K. M.; Zavadskas, E. K. 2009a. Robustness of the multi-objective MOORA method with a test for the facilities sector, Technological and Economic Development of Economy 15(2): 352-375. http://dx.doi.org/10.3846/1392-8619.2009.15.352-375

Brauers, W. K. M.; Zavadskas, E. K. 2009b. Multi-objective optimization with discrete alternatives on the basis of ratio analysis, Intelektine ekonomika - Intellectual economics 2(6): 30-41.

Brauers, W. K. M.; Zavadskas, E. K. 2010a. Project management by MULTIMOORA as an instrument for transition economies, Technological and Economic Development of Economy 16(1): 5-24. http://dx.doi.org/10.3846/tede.2010.01

Brauers, W. K. M.; Zavadskas, E. K. 2010b. Robustness in the MULTIMOORA model, the example of Tanzania, Transformations in Business \& Economics 9(3): 66-83.

Brauers, W. K. M.; Zavadskas, E. K. 2011. MULTIMOORA optimization decides on bank loan to buy property, Technological and Economic Development of Economy 17(1): 174-188. http://dx.doi.org/10.3846/13928619.2011.560632

Brauers, W. K. M.; Zavadskas, E. K. 2012a. Robustness of MULTIMOORA: a method for multi-objective optimization, Informatica 23(1): 1-25.

Brauers, W. K. M.; Zavadskas, E. K. 2012b. A multi-objective decision support system for project selection with an application for the Tunisian textile industry, $E \& M$ Ekonomie a Management 15(1): 28-43.

Brauers, W. K. M.; Zavadskas, E. K. 2013. Multi-objective economic evaluation of the European Union member states as opposed to credit rating agencies opinions?, Transformations in Business \& Economics 12 (2 (29)): 102-124.

Brauers, W. K. M.; Zavadskas, E. K.; Turskis, Z.; Antucheviciene, J. 2006a. Evaluating redevelopment alternatives of buildings with an application of the MOORA method, in International Conference on Operational Research "Simulation and Optimisation in Business and Industry", 17-20 May 2006, Tallinn, Estonia, 131-135.

Brauers, W. K. M.; Ginevičius, R.; Zavadskas, E. K.; Antucheviciene, J. 2006b. The future of sustainable development in some states by application of the MOORA method, Report of the 4th International Conference Citizens and Governance for Sustainable Development CIGSUD 2006, 28-30 September 2006, Vilnius, Lithuania, 156-161.

Brauers, W. K. M.; Ginevičius, R.; Zavadskas, E. K.; Antucheviciene, J. 2007. The European Union in a transition economy, Transformations in Business \& Economics 6(2 (12)): 21-37.

Brauers, W. K. M.; Zavadskas, E. K.; Peldschus, F.; Turskis, Z. 2008a. Multi-objective decision-making for road design, Transport 23(3): 183-193. http://dx.doi.org/10.3846/1648-4142.2008.23.183-193

Brauers, W. K. M.; Zavadskas, E. K.; Turskis, Z; Vilutiene, T. 2008b. Multi-objective contractor's ranking by applying the MOORA method, Journal of Business Economics and Management 9(4): 245-255. http://dx.doi.org/10.3846/1611-1699.2008.9.245-255 
Brauers, W. K. M.; Balezentis, A; Balezentis, T. 2011. MULTIMOORA for the EU Member States updated with Fuzzy Number Theory, Technological and Economic Development of Economy 17(2): 259-290. http://dx.doi.org/10.3846/20294913.2011.580566

Brauers, W. K. M.; Kracka, M.; Zavadskas, E. K. 2012a. Lithuanian case study of masonry buildings from the Soviet period, Journal of Civil Engineering and Management 18(3): 444-456. http://dx.doi.org/10.3846/13923730.2012.700944

Brauers, W. K. M.; Balezentis, A; Balezentis, T. 2012b. European Union member states preparing for Europe 2020. An application of the MULTIMOORA method, Technological and Economic Development of Economy 18(4): 567-587. http://dx.doi.org/10.3846/20294913.2012.734692

Brauers, W. K. M.; Balezentis, A; Balezentis, T. 2012c. Implementing the EU Strategy in Baltic States, a multi-objective evaluation, Actual Problems of Economics 8: 317-329.

Brauers, W. K. M.; Kildiene, S.; Zavadskas, E. K.; Kaklauskas, A. 2013. The construction sector in twenty European countries during the recession 2008-2009 - country ranking by MULTIMOORA, International Journal of Strategic Property Management 17(1): 58-78. http://dx.doi.org/10.1016/j.procs.2014.05.347

Brauers, W. K. M.; Ginevicius, R.; Podvezko, A. 2014a. Ranking of the Lithuanian banks during the recession of 2008-2009 by the MULTIMOORA method, Annals of Management Science 3(1): 1-8.

Brauers, W. K. M.; Ginevicius, R.; Podvezko, A. 2014b. Development of a methodology of evaluation of financial stability of commercial banks, Panoeconomicus 61(3): 349-367. http://dx.doi.org/10.2298/PAN1403349B

Brauers, W. K. M.; Zavadskas, E. K.; Kildiene, S. 2014c. Was the construction sector in 20 European countries anti-cyclical during the recession years 2008-2009 as measured by multicriteria analysis (MULTIMOORA)?, Procedia Computer Science 31: 949-956. http://dx.doi.org/10.1016/j.procs.2014.05.347

Kirshen, E. S.; de Falleur, R. 1958. Analyse input-output de l' Economie belge. Dulbea, Brussels.

Kračka, M.; Brauers, W. K. M.; Zavadskas, E. K. 2010. Ranking heating losses in a building by applying MULTIMOORA, Inzinerine Ekonomika - Engineering Economics 21 (4): 352-359.

MacCrimmon, K. R. 1968. Decision making among multiple attribute alternatives. A survey and consolidated approach, Rm-4823- Arpa. The Rand Corporation, Santa Monica, Cal.

Hatem MASRI is an Associate Professor at the College of Business Administration, in the University of Bahrain, Kingdom of Bahrain. He received a PhD in Management in 2004 and a master in Operations research in 1999 from the University of Tunis, Tunisia. His research interests include multiple objective stochastic programming, supply chain management, financial economics, and vehicle routing problems. His research has been published in several international journals (EJOR, FSS, IJAR ...) and funded by the University of Tunis, the University of Nizwa and the University of Bahrain. He edited several books and special issues in international journals and chaired some international conferences and acted as a committee member in several international conferences. Dr. Hatem is member of the International Society on Multiple Criteria Decision Making, IEEE and Tunisian Decision Aid Society. 